This work is licensed under Creative Commons Attribution 4.0 International (CC BY 4.0). [http://creativecommons.org/licenses/by/4.0/]

\title{
System internetowej rejestracji osób pozostających bez zatrudnienia jako element nieskutecznej polityki zatrudnienia
}

Mateusz Rutkowski | Uniwersytet Gdański, Wydział Nauk Społecznych https://orcid.org/0000-0003-4050-402X

Słowa kluczowe:

bezrobocie, rynek pracy, wsparcie instytucjonalne, pomoc

Keywords: unemployment, labour market, institutional support, assistance

\section{Streszczenie}

W artykule zostały opisane dwie formy wsparcia osób bezrobotnych w Polsce: rejestracja, będąca początkiem podejmowania działań aktywizujących, oraz aktywizacja zawodowa. Autor analizuje system internetowej rejestracji osób bezrobotnych w kontekście użyteczności i dostosowania do możliwości wykorzystania go przez osoby pozostające bez pracy. W rezultacie dochodzi do wniosku, że tak funkcjonujący system jest bardziej wykluczający niż wspierający. Głównym argumentem, który to potwierdza, jest konieczność posiadania zaawansowanych umiejętności obsługi urządzeń komputerowych. Jak pokazuje autor, trudności już na etapie rejestracji oraz wielość czynności nadzorczych ze strony urzędu skutecznie redukują motywację osób bezrobotnych do podejmowania działań.

\section{Online registration system for unemployed persons as part} of an ineffective employment policy

\section{Summary}

The article describes two forms of support for the unemployed in Poland: registration, which is the beginning of activating activities, and economic activation. The author analyses the system of Internet registration of the unemployed in the context of usability and adaptation to the possibility of using it by the unemployed. As a result, the conclusion is that such a system is more exclusionary than supportive. The main argument that confirms this is the need for advanced computer skills. As the author shows, difficulties already at the registration stage and the multitude of supervisory activities on the part of the office effectively reduce the motivation of the unemployed to take action. 


\section{Wstęp}

Temat pozostawania bez zatrudnienia od dłuższego czasu wydaje się być mało atrakcyjny dla mediów, których doniesienia zazwyczaj odwołują się do ujęć stricte statystycznych ${ }^{1}$. Narracje medialne ograniczają się do określania sytuacji na rynku pracy za pomocą wskaźników ekonomicznych. Odnoszą się między innymi do spadającej ilości osób bezrobotnych na poziomie regionalnym oraz ogólnokrajowym.

Obecną sytuację na rynku pracy należy określić jako trudną. Z jednej strony mamy do czynienia ze spadającym bezrobociem, z drugiej zaś - z problemem ze znalezieniem pracowników przez przedsiębiorców. W obszarze zatrudnienia można wskazać więcej utrudnień, między innymi: konieczność zatrudniania obcokrajowców, niedostateczne kwalifikacje kandydatów, a także rosnące oczekiwania pracowników względem płac, których nie są w stanie spełnić przedsiębiorcy (Raport Work Service: Barometr Rynku Pracy X, 2018). Warto także wspomnieć o spadku aktywności zawodowej kobiet, związanej z korzystaniem ze świadczeń programu „Rodzina 500+" (porp.pl). W wielu przypadkach środki te pozwalają zaspokoić potrzeby na minimalnym poziomie, jednocześnie osłabiając motywację do podjęcia pracy.

Pewnym rozwiązaniem tej sytuacji jest aktywizacja osób bezrobotnych zrejestrowanych w urzędach. Instytucją predestynowaną do wspierania w sytuacji bezrobocia są zgodnie z art. 33 ustawy z dnia 20 kwietnia 2004 roku o promocji zatrudnienia i instytucjach rynku pracy powiatowe urzędy pracy. Ich zadaniem jest rejestracja bezrobotnych, wypłata należnych świadczeń oraz aktywizacja zawodowa.

W artykule zostaną omówione dwie z wymienionych form współpracy - pierwsza i ostatnia, mianowicie rejestracja oraz aktywizacja. Tekst ten jest między innymi rezultatem moich doświadczeń wynikających ze współpracy z urzędem pracy. Używając nomenklatury metodologicznej, należałoby ją umiejscowić w obrębie obserwacji uczestniczącej. Zakres czasowy czynności badawczych obejmuje drugie półrocze 2017 roku.

Celem podejmowanych czynności badawczych i analiz jest ukazanie sposobu działania instytucji aktywizacji zawodowej (w tym przypadku powiatowego urzędu pracy) z perspektywy beneficjenta. Głównym obszarem analizy jest pierwszy etap współpracy, jakim jest rejestracja w urzędzie. Jednocześnie jest to próba oceny skuteczności działań instytucji oraz wskazanie potencjalnych kierunków zmiany.

\footnotetext{
${ }^{1}$ Wniosek ten wywodzi się z analizy tekstów medialnych dotyczących bezrobocia. Badanie to jest częścią obronionej przeze mnie w 2017 roku pracy magisterskiej pt. „Bezrobotny, to znaczy kto? O konstruowaniu obrazu osoby pozostającej bez zatrudnienia", napisanej pod kierunkiem prof. dr hab. Marii Mendel.
} 


\section{Przeciwdziałanie bezrobociu jako element polityki społecznej}

Polityka społeczna definiowana jest jako intencjonalna działalność organizacji rządowych i pozarządowych, której celem jest wyrównywanie życiowych szans społeczeństwa i zaspokajanie różnorodnych potrzeb społecznych (Bednarz 2016). Obszarami, którymi zajmuje się polityka społeczna, są między innymi sfery: mieszkaniowa, ochrony zdrowia, oświaty, ochrony środowiska, prewencji zachowań dysfunkcyjnych oraz rynku pracy i zatrudnienia (Polak 2009). Wśród nich najważniejsza wydaje się być ta ostatnia, wiążąca się z pracą. Przypisanie tak znaczącej roli zatrudnieniu wynika z uznania pracy jako podstawowej czynności pozwalającej realizować potrzeby życiowe człowieka (Stańczyk 2013: 108-122). Posiadanie pracy lub jej brak decyduje o tym, w jakim zakresie korzysta się z rozwiązań przewidywanych w ramach prowadzonej polityki społecznej.

W ujęciu ekonomicznym bezrobocie rozumiane jest jako pozostawanie bez pracy przez ludzi w wieku produkcyjnym, zdolnych i gotowych do podjęcia pracy (Auleytner 2011:220). Istotnym warunkiem jest także podejmowanie poszukiwań pracy przez bezrobotnych (Kryńska, Kwiatkowski 2013: 113). Pozostawanie bez zatrudnienia jest sytuacją wymagającą szczególnego zainteresowania, ponieważ powoduje wiele negatywnych skutków, które nie dotyczą wyłącznie sfery ekonomicznej (Konat 2009: 31). Wśród nich można wymienić: utratę motywacji do pracy, negatywne postrzeganie siebie i swojej przyszłości, rozpad relacji międzyludzkich (rodzinnych i społecznych) oraz konsekwencje zdrowotne (zarówno choroby, jak i szkody psychologiczne). Brak pracy jest przyczyną korzystania ze wsparcia instytucjonalnego, co potwierdzają analizy Głównego Urzędu Statystycznego. Prawie 50\% ubogich (osiągających dochody poniżej kryterium) korzysta ze środowiskowej pomocy społecznej ze względu na bezrobocie (GUS 2016).

Problem bezrobocia znajduje odzwierciedlenie w dwóch elementach polityki społecznej: polityce zatrudnienia oraz polityce rynku pracy. Polityka zatrudnienia podejmuje działania w celu umożliwienia jak najpełniejszego zatrudnienia. Skupia się na zapobieganiu bezrobociu oraz łagodzeniu skutków jego występowania (Magierek 2009: 121). Polityka rynku pracy w tym obszarze obejmuje dwa rodzaje działań: aktywne i pasywne (Orczyk 2008: 101). W praktyce chodzi kolejno o stwarzanie warunków, które umożliwiają ponowne włączenie w rynek pracy oraz o dostarczanie środków finansowych niezbędnych do egzystencji. Jak wskazuje Tomasz Budnikowski (2009: 155), istotniejsze oraz efektywniejsze jest kładzenie nacisku na aktywizację.

Niezależnie od stosowanych działań mających na celu ponowne włączenie w rynek pracy podstawową czynnością pozwalającą na skorzystanie ze wsparcia instytucjonalnego jest rejestracja we właściwym urzędzie pracy. Warto także nadmienić, że od jakości współpracy z instytucją zależy, czy dana osoba odniesie aktywizacyjny sukces. 


\section{Dwie możliwości rejestracji}

Pierwszym zadaniem, które stoi przed osobą nieaktywną zawodowo, jest rejestracja we właściwym powiatowym urzędzie pracy. Można tego dopełnić na dwa sposoby: udając się osobiście do instytucji wraz z niezbędną dokumentacją lub rejestrując się przez Internet za pośrednictwem strony praca.gov.pl. Rejestracja internetowa została udostępniona 27 maja 2013 roku na mocy rozporządzenia Ministra Pracy i Polityki Społecznej z dnia 12 listopada 2012 roku w sprawie rejestracji osób bezrobotnych i poszukujących pracy.

Celem takiego działania było usprawnienie procesu rejestracji: jako ułatwienie pracy urzędnikom oraz skrócenie czasu wizyty w instytucji po stronie potencjalnego klienta poprzez ustalenie konkretnego terminu i godziny spotkania z przedstawicielem urzędu.

W przypadku rejestracji internetowej również istnieją dwie możliwości. Pierwsza nie wymaga osobistego stawiennictwa w urzędzie, w zamian zobowiązujemy się załączyć podczas rejestracji skany wszystkich wymaganych dokumentów. Wniosek o rejestrację należy podpisać kwalifikowanym podpisem elektronicznym lub podpisem potwierdzonym profilem zaufanym ePUAP (Elektroniczna Platforma Usług Administracji Publicznej). Na uwagę zasługuje fakt, że korzystanie ze wspomnianej platformy jest bezpłatne, zaś wyrobienie kwalifikowanego podpisu elektronicznego to koszt około dwustu złotych (szafir.kir.com.pl). Jest więc to dobro, które ze względu na brak środków finansowych nie jest przeznaczone dla osób biernych na rynku pracy.

W tym miejscu należy podkreślić, że w 2014 roku z ePUAP-u korzystało zaledwie 1\% dorosłych Polaków, a w roku 2013 Polacy załatwili za jego pośrednictwem niewiele ponad 11 tysięcy spraw (Czubkowska, Zieliński 2014). Głównymi użytkownikami platformy ePUAP są urzędnicy. Taki stan rzeczy pozwala domniemywać, że bardzo niewiele osób korzysta z tego systemu do rejestracji i załatwiania innych spraw w urzędach, także w urzędach pracy. Problem ten nie wydaje się być istotnym. Mamy bowiem możliwość wstępnego wypełnienia dokumentów w domowym zaciszu (jeśli oczywiście posiadamy dostęp do Internetu), a do urzędu idziemy na określoną godzinę. Wróćmy więc do dalszej rejestracji.

\section{Etap pierwszy: dane osobowe i uprawnienia}

Pierwszym etapem jest wypełnienie formularza, na podstawie którego zostaje ustalony status osoby bezrobotnej. Lista obejmuje 20 pytań, na której należy zaznaczyć właściwą ze stanem faktycznym odpowiedź - twierdzącą lub przeczącą. Wśród nich znajdują się kwestie dotyczące: nauki w trybie stacjonarnym, gotowości do podjęcia zatrudnienia, pobieranych świadczeń (zarówno z Zakładu Ubezpieczeń Społecznych, ośrodków pomocy społecznej, jak i Funduszu Pracy), prowadzenia działalności 
gospodarczej, odbywania kary pozbawienia wolności oraz posiadanych orzeczeń o stopniu niepełnosprawności (praca.gov.pl:a).

Kolejnym etapem jest uzupełnienie danych osobowych, takich jak imiona, nazwisko, adres zameldowania/tymczasowy/przebywania, PESEL, imiona rodziców oraz obywatelstwo. Na tym etapie rejestracji system wymaga załączenia dokumentu potwierdzającego tożsamość. Najlepiej jeśli jest to skan, jednak może to być również zdjęcie dokumentu, który (jak się okaże później) zostanie zweryfikowany podczas pierwszej wizyty w urzędzie. Wymóg ten stanowi pewnego rodzaju barierę w procesie rejestracji; osoby starsze, nieposiadające odpowiedniego sprzętu lub niepotrafiące obsługiwać komputera w takim zakresie, nie są w stanie przejść do dalszego etapu. Jest to pierwszy element, który demotywuje osobę pozostającą bez zatrudnienia, ponieważ w skrajnym przypadku może powodować myślenie w kategorii „Nie potrafię obsłużyć komputera, nie mogę się nawet zarejestrować, jak więc mam odnaleźć się na rynku pracy?".

Następnym krokiem jest uzupełnienie danych dotyczących posiadanego wykształcenia, następnie zawodu (zawodów) wraz ze stażem oraz znajomości języków obcych. W dwóch ostatnich przypadkach posługujemy się listą rozwijaną lub możemy wspomóc się, wpisując nazwę zawodu, a system podpowie nam możliwości.

Sytuacja ulega diametralnej zmianie, kiedy jesteśmy na etapie posiadanych uprawnień. Komplikuje się, ponieważ system nie posiada wszystkich możliwych opcji, a nie daje również możliwości ręcznego wypełnienia posiadanych kwalifikacji. Bezrobotny w wielu przypadkach musi dopasować posiadane zaświadczenia o uprawnieniach do możliwości przewidzianych przez system. A możliwości jest bardzo wiele. Szczególnej uwagi wymaga techniczne poruszanie się po stronie - rejestrujący korzysta z rozwijanej listy umiejętności, ułożonej w sposób alfabetyczny. Na jednej stronie znajduje się dziesięć możliwości oraz opcje „poprzednie wybory" $i$ „więcej wyborów”, które pokażą nam odpowiednio wcześniejsze lub następne opcje.

Pierwszym istotnym problemem jest to, że wybierając jedno uprawnienie, system zwija listę, a po zapisaniu zmian, aby przejść do dalszych możliwości, należy przejść przez wszystkie od początku. Każde błędne kliknięcie lub zbyt długie zastanawianie się powoduje odświeżenie witryny, co po raz kolejny zmusza do śledzenia listy uprawnień od nowa. Nie byłoby to problematyczne, gdyby nie fakt, że możliwości jest ponad 3500 (na dzień 29.06.2018 dokładnie 3559 pozycji), co w przeliczeniu na dziesięć możliwości na stronę daje nam 356 stron umiejętności. Taka ilość elementów do prześledzenia wymaga dużej cierpliwości oraz ogromnego samozaparcia. Konieczny jest także spory zasób czasu, bowiem nie można rozpoczętej czynności odłożyć w czasie i odpocząć (chociażby ze względu na zmęczenie wzroku). W takiej sytuacji system odświeża się, a wszystkie dotychczasowe zmiany zostają utracone. 


\section{Etap drugi: umiejętności i kwalifikacje}

Inną trudnością, z którą bezrobotny musi zmierzyć się na tym etapie rejestracji, jest używane nazewnictwo poszczególnych uprawnień. Należy mieć na uwadze, że różne uprawienia możemy nazywać w różny sposób. I tak, dla przykładu, mając ukończony kurs języka angielskiego, osoba ubiegająca się o rejestrację w urzędzie musi zdecydować, czy posiada: ,certyfikat języka angielskiego",,,język angielski - poziom podstawowy" ",język angielski - stopień podstawowy", ,język angielski na poziomie elementary" "język angielski stopień podstawowy rozszerzony" "kurs certyfikacyjny języka angielskiego", ,kurs języka angielskiego", ,kurs języka angielskiego A2" „kurs języka angielskiego w stopniu podstawowym”, „nabycie wiadomości i umiejętności z zakresu komunikowania się w j. angielskim”, „podstawy języka angielskiego" czy też „podstawowa nauka języka angielskiego". Wszystkich opcji wyboru na liście związanych z językiem angielskim jest 53 .

Ten etap rejestracji to nie tylko trudność związana z odnalezieniem i wybraniem posiadanego uprawnienia, ale przede wszystkim określeniem, jakie umiejętności się posiada, co w przypadku tak wielu możliwości jest wyjątkowo trudne. Wybór odpowiedniej nazwy umiejętności wiąże się z obawą przed niewłaściwym określeniem oraz wizją możliwych konsekwencji ze strony urzędu, jeśli wybrane określenie nie odpowiada stanowi faktycznemu. Obawa ta jest uzasadniona, ponieważ osoba dokonująca rejestracji już na pierwszej stronie zapewnia, że wprowadzone dane są zgodne ze stanem faktycznym oraz że bierze odpowiedzialność za ewentualne rozbieżności (znajdujemy tam następujący zapis: „Uprzedzony(a) o odpowiedzialności karnej z art. 233 $\S 1$ kodeksu karnego za składanie fałszywych zeznań, oświadczam, co następuje: ...") (tamże).

Opisana wcześniej sytuacja mnogości wyborów ponownie przejawia się w kolejnym kroku, kiedy osoba ubiegająca się o rejestrację w urzędzie ma za zadanie uzupełnić listę posiadanych umiejętności. Po raz kolejny jest to lista rozwijana, tym razem posiada 1228 pozycji. Warto także zwrócić uwagę na pojawiające się możliwości, wśród których odnajdziemy: „prawo jazdy kat. B”, ,aktywna sprzedaż”, „aktywność społeczna”, ,bezpieczna obsługa urządzeń kuchennych", ,certyfikat masażu stemplami ziołowymi", , dyspozycyjność", , dokładność", „,komunikatywna znajomość języka angielskiego", ,jazda konno", "gra na skrzypcach", ,koordynator", ,kurs krawcowej", ,liczenie w pamięci", ,Microsoft Word 2003 - poziom podstawowy", ,"min. 5 lat doświadczenia zawodowego" (praca.gov.pl:b).

Pierwszy wniosek, jaki wyłania się z analizy tej części materiału, można określić w następujący sposób: podstawowym problemem jest rozróżnienie między umiejętnościami a kwalifikacjami. Niewłaściwy podział wiąże się także z zawahaniem w ocenie własnych kwalifikacji i odpowiedzi na pytanie, czy konkretna umiejętność jest bardziej uprawieniem czy umiejętnością. Wątpliwość ta jest wzmacniana przez pojawianie się wśród możliwości predyspozycji oraz cech miękkich - między innymi dokładności, 
sumienności, dyspozycyjności. Kolejne opcje wyboru powodują konieczność podjęcia następnych decyzji, które z kolei mogą stać się przyczyną rosnącej niechęci, zarówno do realizacji dalszych etapów rejestracji w urzędzie, jak i urzędu w ogóle. Należy pamiętać, że zazwyczaj nie oddzielamy systemu obsługi klienta danej instytucji od ich przedstawicieli; wydając opinię, domyślnie odwołujemy się do samej instytucji.

Mając za sobą kolejny trudny etap, osoba ubiegająca się o rejestrację w urzędzie pracy w następnej zakładce uzupełnia informacje o ostatnim miejscu zatrudnienia (jeśli takie posiada), okresie zatrudnienia oraz o przyczynach jego ustania, by w kolejnym etapie móc poszerzyć dane o całą historię życia zawodowego.

Przedostatnim krokiem rejestracji za pośrednictwem Internetu jest uzupełnienie informacji o członkach swojej rodziny z uwzględnieniem możliwości ich ubezpieczenia. Ostatni etap dotyczy oczekiwań osób zgłaszającej się do instytucji jako bezrobotna zarówno w kwestii wykonywania przyszłego zawodu, jak i możliwości przyuczenia się do wykonywania danej profesji. Początkowo może wydawać się, że pytanie o oczekiwania jest jak najbardziej zasadne, ze względu na możliwość skierowania danej osoby do konkretnej pracy czy na konkretne szkolenie. Takie pytanie wiąże się z dwiema trudnościami - praktyczną oraz techniczną.

Trudność ze strony praktycznej polega na konieczności uświadomienia sobie przez osobę bierną na rynku pracy, co chce robić w dalszym życiu zawodowym oraz tego, czego robić nie chce. Wymaga to wysokiej samoświadomości w kwestii znajomości siebie, umiejętności określenia swoich potrzeb oraz planowania swojej przyszłości. Takie zadanie może okazać się trudne do wykonania przez osoby posiadające niską samoocenę, wśród których znajdują się z pewnością osoby nieposiadające zatrudnienia. Z kolei trudność techniczna ponownie wiąże się z koniecznością posługiwania się rozwijaną listą umiejętności, którą omówiono we wcześniejszych rozważaniach. W konsekwencji osoba bezrobotna może dojść do wniosku, że nie ma żadnych oczekiwań w odniesieniu do przyszłej kariery zawodowej.

Dokonana analiza pozwala stwierdzić, że system stworzony dla ułatwienia procesu rejestracji osób nieposiadających zatrudnienia nie spełnia swojej roli. Wielość elementów, różnorodność możliwości, a przede wszystkim brak jasności stwierdzeń są utrudnieniem już w pierwszym kroku do przezwyciężenia trudnej sytuacji życiowej. Stworzony system ujawnia brak empatii przedstawicieli instytucji pomocowej względem jej odbiorców. Urząd pracy winien mieć świadomość, że proces rejestracji internetowej powinien być bardziej intuicyjny - chociażby ze względu na osoby, które nie potrafią w pełni lub w ogóle obsługiwać komputera. Oczywiście, beneficjenci mający trudności mogą skorzystać ze standardowej procedury rejestracji poprzez wizytę w urzędzie. Jednakże należy pamiętać o celu, który miała spełniać internetowa platforma rejestracji. W intencji ustawodawcy miała zdecydowanie ułatwić dostęp do urzędu oraz skrócić czas rejestracji. 
Warto spojrzeć na tę kwestię także z perspektywy istnienia rozwijanych list umiejętności, stanowiących zamknięty katalog możliwości. Nie można stwierdzić, że wspomniane katalogi wyczerpują wszystkie możliwości opcji wyboru. W związku z czym istnieje duże prawdopodobieństwo, że rejestrujący będzie posiadał umiejętności lub uprawnienia wykraczające poza przewidziane opcje. W rezultacie będzie uciekał się do wyborów opcji z listy, które jego zdaniem są najbliższe posiadanej kwalifikacji. Ocena ta nie musi być trafna.

\section{Etap trzeci: wizyta w urzędzie}

Zaletą rejestracji za pośrednictwem Internetu jest ustalenie dokładnego terminu i godziny wizyty w urzędzie. Wydaje się, że pozytywne strony przyjętego rozwiązania na tym się wyczerpują. Po trudnościach związanych z procesem rejestracji internetowej kolejnym krokiem jest stawiennictwo na ustalonej wizycie. System przydziela nam najbliższy wolny termin, podając datę i godzinę spotkania, na które należy zabrać całą posiadaną dokumentację, o której system informował nas w pierwszym kroku. Ponadto należy dostarczyć te dokumenty, które wprowadziliśmy w pozostałych krokach - informacje o kwalifikacjach, umiejętnościach, orzeczenie o stopniu niepełnosprawności itd.

Wprost nasuwa się pytanie o sens umieszczania wszelkich informacji w systemie podczas rejestracji, jeśli dokumentację trzeba dostarczyć do urzędu. Jedną z możliwości jest kwestia ich weryfikacji przez pracownika urzędu, co jednak w dalszym ciągu stwarza perspektywę podwójnej pracy z tym samym dokumentem. Taka sytuacja w oczach beneficjenta ukazuje się jako brak zaufania instytucji wobec składanych przez niego deklaracji, co nie stwarza pola do ukonstytuowania się pozytywnych relacji dla dalszej pracy pomocowej.

Innym problemem wiążącym się z weryfikacją wypełnionego przez Internet zgłoszenia jest wymaganie dokumentów potwierdzających każdą zaznaczoną umiejętność i uprawnienie. Dotyczy to także tych opcji, które osoba zaznaczyła jako deklaratywne. W praktyce oznacza to, że jeśli osoba rejestrująca się w urzędzie pracy zadeklarowała w systemie umiejętność obsługi poczty elektronicznej to podczas pierwszej wizyty musi przedstawić zaświadczenie potwierdzające posiadanie takich kwalifikacji.

W wyniku tak prowadzonej pierwszej rozmowy osoba pozostająca bez zatrudnienia otrzymuje szereg negatywnych informacji zwrotnych. Najpierw instytucja mówi, że nie ufa bezrobotnemu, po czym podaje w wątpliwość posiadane kwalifikacje, $w$ rezultacie czego można dowiedzieć się, że potrafi się mniej niż się wydawało. Nie są to elementy budujące pozytywną współpracę oraz motywujące bezrobotnego do przezwyciężenia trudności życiowych. Wręcz przeciwnie - przekonują one osobę bierną na rynku pracy, że sytuacja, w której się znajduje, jest wyjątkowo trudna do rozwiązania. 
Drugim etapem wizyty jest przekierowanie do innego stanowiska, w którym dokumenty po raz kolejny są weryfikowane oraz uzupełniane w systemie. To także moment, kiedy pracownik urzędu skupia się na historii zatrudnienia oraz wymaga ewentualnego uzupełnienia dokumentacji. Niestety, po raz kolejny ujawnia się tutaj brak empatii. Termin na doniesienie braków w dokumentacji to siedem dni roboczych, co w przypadku konieczności uzyskania zaświadczenia od pracodawcy, posiadającego siedzibę w dalekiej odległości od miejsca zamieszkania osoby bezrobotnej, jest trudne do zrealizowania. Problem polega także na tym, że beneficjent musi dostarczyć oryginał dokumentu - nie może być to skan. W związku z tym były pracodawca musiałby wystawić stosowne zaświadczenie od ręki, aby zostało doręczone przed kolejną wizytą w urzędzie.

Kiedy wszystkie dokumenty zostały zweryfikowane, a profil ustalony, bezrobotny zostaje przekierowany do doradcy zawodowego, z którym będzie współpracować w późniejszym czasie. Po tak wielu trudnościach związanych z biurokracją nadzieja na znalezienie zatrudnienia i zmianę swojej sytuacji odżywa na nowo.

Współpraca z doradcą ogranicza się do trzech elementów: przedstawiania bieżących ofert pracy, rozmowy o planach zawodowych na przyszłość oraz weryfikacji tego, czy bezrobotny faktycznie podejmuje we własnym zakresie aktywności mające na celu znalezienie pracy. Termin kolejnej wizyty przypada na dwa tygodnie po pierwszej, a każda następna zazwyczaj odbywa się co trzy miesiące. Trudno więc mówić o aktywnym działaniu na rzecz przezwyciężenia trudnej sytuacji życiowej, jeśli aktywność instytucji predestynowanej do tego rodzaju wsparcia ogranicza się do tak rzadkich spotkań. Środek ciężkości działań aktywizacyjnych jest zdecydowanie przesunięty w stronę osoby biernej na rynku pracy. A to niestety pozwala wnioskować, że bezrobotny nie potrzebuje instytucji, aby znaleźć zatrudnienie. Urząd jest mu niezbędny jedynie do otrzymania zasiłku lub ubezpieczenia zdrowotnego dla siebie i/lub rodziny.

\section{Nauka, która „poszła w las”}

Przedstawiony system rejestracji osób biernych zawodowo nie do końca odpowiada potrzebom i celom, jakim ma służyć. Dokonana analiza może świadczyć o braku świadomości przedstawicieli instytucji o tym, z jakimi trudnościami życiowymi wiąże się pozostawanie bez pracy. Tak skomplikowany system rejestracji z pewnością nie ułatwia realizacji tego zadania zarówno bezrobotnemu, jak i urzędnikowi. Klient spotyka liczne trudności w rejestracji przez Internet, zaś urzędnik musi dokonać weryfikacji zgłoszenia.

Trudności, z którymi muszą zmierzyć się bezrobotni, dotyczą różnych obszarów. Najpierw dotyczą one sfery ekonomicznej (posiadanie odpowiedniego sprzętu komputerowego czy posiadanie kwalifikowanego podpisu), umiejętności (obsługi komputera, skanera), by w dalszych etapach dotknąć kwestii bardziej osobistych (weryfikacji umiejętności, decyzji o tym, w jakich kategoriach określić swoje uprawnienia). Szczególnej 
uwagi wymagają trudności związane z samooceną, które mogą negatywnie oddziaływać na postrzeganie samego siebie, a to z pewnością nie jest elementem korzystnie wpływającym na współpracę i przezwyciężanie trudności życiowych.

Opisana rzeczywistość przywodzi na myśl używane przez Pierre’a Bourdieu pojęcie "segregacji instytucjonalnej" (Hinc 2009: 15). Klasyczne rozumienie tego pojęcia odnosi się do szkolnego manifestowania różnic klasowych mających odzwierciedlenie, między innymi, w używanym przez kadrę nauczycielską języku. W przypadku opisanej $w$ artykule instytucji rynku pracy przyjmuje ona przynajmniej dwie formy. Pierwsza, tak jak u Bourdieu, odnosi się do używanego języka, do konieczności określenia swoich predyspozycji w pewnego rodzaju ramach. Druga zaś dotyczy sfery możliwości i umiejętności - w tym przypadku, najogólniej mówiąc, chodzi o możliwość posługiwania się nowoczesnymi technologiami (obsługiwania komputera czy umiejętności poruszania się po systemie internetowej rejestracji). To z kolei może wiązać się z wykluczeniem ekonomicznym, którego bezrobotni doświadczają wielokrotnie.

Konkluzja w oparciu o teorię Bourdieu może przyjąć następującą formę: instytucja urzędu pracy dokonuje segregacji osób pozostających bez zatrudnienia na takie, które posiadają zasoby i umiejętności niezbędne do rejestracji w instytucji, oraz takie, które ich nie posiadają. To z kolei oznacza ograniczony dostęp do zaspokajania potrzeb, do czego niezbędna jest praca zarobkowa. Segregacja, o której mowa, w pewien sposób być może zawoalowany - określa, komu należy pomóc, a komu nie.

Nakreślona sytuacja przypomina polską politykę „zaciskania pasa” mającą miejsce w czasie kryzysu gospodarczego, o której pisała m.in. Maria Theiss (Theiss i in. 2017: 14-15). Wówczas dotyczyła ona prowadzenia oszczędnych działań w sferze ekonomicznej, mającej na celu redukcję kosztów społecznych. Dziś zaś, w perspektywie rozważań niniejszego artykułu, można doszukiwać się jej w pewnego rodzaju utrudnianiu dostępu do wsparcia instytucjonalnego, co niewątpliwie należy do działań o charakterze oszczędnościowym. Trudno jednoznacznie wskazać, w którym miejscu się przejawia. Wracając jednak do konkluzji, które już się pojawiły: urząd pracy segreguje bezrobotnych, w związku z czym u części z nich pojawia się niechęć do korzystania ze wsparcia instytucjonalnego, co wpływa na redukcję motywacji do przezwyciężenia trudnej sytuacji życiowej, a dla systemu wsparcia oznacza zwyczajną oszczędność. Warto jednak odpowiedzieć sobie na pytanie, czy oszczędzanie środków w obszarze wsparcia osób biernych na rynku pracy przynosi realne korzyści dla państwa i społeczeństwa.

Omawiając system dedykowany osobom biernym na rynku pracy, należałoby przywołać dotychczasowe doświadczenia ówczesnego Ministerstwa Pracy i Polityki Społecznej wynikające z udostępnienia platformy powszechnie znanej pod nazwą"emp@tia”. Strona, o której mowa, to portal informacyjno-usługowy przeznaczony do obsługi osób poszukujących wsparcia z systemu pomocy społecznej, w tym osób bezdomnych (Kto zarobiłnaEmp@tii?..., 2014). 
Głównym argumentem podejmowanym przez media w tym temacie był fakt niedopasowania do realnych potrzeb, ponieważ trudno mówić o korzystaniu osób bezdomnych z internetowej platformy obsługi. Jak zostało podkreślone w przytoczonym artykule, korzystanie z emp@tii stanowi podstawę do traktowania świadczeń, z których korzysta osoba używająca platformy internetowej, jako nienależnie pobranych, ponieważ absurdalna jest sytuacja, gdy osoba korzystająca ze świadczeń pomocy społecznej korzysta z Internetu (oznacza to przecież, że posiada zasoby pieniężne). Finalnie, w momencie uruchomienia system spełniał jedną funkcję - zbierania danych statystycznych ułatwiających dystrybucję środków wydatkowanych na pomoc społeczną. Możliwe, że rozwiązanie to było niezbędne dla usprawnienia procesów administracyjnych. Trudno jest jednak wskazać na korzystne efekty po stronie świadczeniobiorców.

Zbliżona sytuacja dotyczy strony praca.gov.pl, przeznaczonej do rejestracji osób pozostających bez zatrudnienia. Bezcelowe wydaje się przytaczanie trudności po raz kolejny. Warto zwrócić uwagę na dwie kwestie: konieczności posiadania sprzętu komputerowego z dostępem do Internetu oraz umiejętności obsługi strony. Z obiema rzeczami osoby bierne na rynku pracy mogą sobie nie poradzić.

\section{Zakończenie}

Opisany sposób rejestracji osób pozostających bez zatrudnienia w kontekście oferowanego wsparcia instytucjonalnego warto przeanalizować w perspektywie pedagogicznej (a właściwie andragogicznej, bowiem wsparcie dedykowane jest osobom dorosłym) jako pewnego rodzaju doświadczenie edukacyjne. Jak pisze Alicja Jurgiel-Aleksander, jednym ze sposobów, w jaki andragodzy traktują doświadczenie edukacyjne, odnosi się do konsekwencji wynikających z umieszczenia jednostki w strukturze, co stanowi „źródło deficytów poznawczych, a nie jest siłą napędową" (Jurgiel-Aleksander 2013: 16).

Zarówno w opisywanym kontekście, jak i rzeczywistości w ogóle osoby pozostające bez zatrudnienia społecznie umieszczone są w niższej części struktury niż pracująca część społeczeństwa. Pozostają w pewnej relacji zależności - względem pracujących (ze względu na finansowanie świadczeń z budżetu państwa) i instytucji pomocowej. Dokonane analizy potwierdzają, że miejsce bezrobotnych w strukturze jest elementem demotywującym ich do podejmowania działań ukierunkowanych na zmianę sytuacji życiowej.

Nowe technologie, korzystanie z komputera i Internetu są niemal nieodłącznym elementem naszej codzienności (Rutkowski 2018: 76). Warto jednak pamiętać, że podążanie za trendami funkcjonowania społeczeństwa wymaga wdrażania, przyuczania i stwarzania możliwości korzystania z nowych rozwiązań.

Kluczową sprawą jest refleksja, budowanie świadomości w obszarze problemów, z jakimi zmagają się osoby z różnego rodzaju trudnościami życiowymi. Sposobem 
na realne ułatwienie procesu rejestracji, zarówno osobom pozostającym bez zatrudnienia, jak i pracownikom instytucji pomocowej, jest konsultacja z reprezentantami tych grup, bowiem to oni najlepiej wiedzą, jakie są realne potrzeby w tym zakresie.

Dotychczasowe doświadczenia Ministerstwa Rodziny, Pracy i Polityki Społecznej płynące zarówno z utworzenia portalu emp@tia, jak i tego, który jest dedykowany osobom biernym na rynku pracy, nie napawają optymizmem. Jest to niestety przykład mówiący o tym, że ustawodawca nie uczy się na własnych błędach. Przyjęte rozwiązanie nie spełnia swojej roli. Prowadzi to do konstatacji, że działania w obszarze aktywizacji zawodowej osób bezrobotnych są nieskuteczne. W obecnej sytuacji rynku zatrudnienia oraz mając do czynienia z takimi przejawami wsparcia instytucjonalnego, bezrobocie można postrzegać w sposób konserwatywny, jako marnowanie zasobów pracy (Auleytner 2011: 89). Ich właściwe „uruchomienie” może okazać się skuteczną siłą napędową rozwoju przedsiębiorstw, a przez to gospodarki narodowej.

\section{Bibliografia}

Auleytner J., 2011, Polityka społeczna w Polsce i w świecie, Warszawa.

Bednarz M., 2016, Zmiany i trendy w polityce społecznej [w:] K. Chaczko, K.M. Stanek (red.), Polityka społeczna w zmieniającej się rzeczywistości, Katowice.

Beneficjenci środowiskowej pomocy społecznej w 2015 r. 2016, GUS, Warszawa.

Budnikowski T., 2009, Bezrobocie wyzwaniem współczesności, Poznań.

Czubkowska S., Zieliński R., 2014, ePUAP kosztuje miliony, a mało kto z niego korzysta „,'Dziennik Gazeta Prawna", forsal.pl/artykuly/773790,epuap-kosztuje-miliony-a-malo-kto-z-niego-korzysta.html [dostęp: 29.06.2018].

Hinc S., 2009, Pierre Bourdieu o edukacji i społeczeństwie oraz reprodukcji kulturowej, „Przegląd Naukowo-Metodyczny. Edukacja dla Bezpieczeństwa", nr 3, Poznań.

https://www.porp.pl/pl/kobiety-wciaz-w-mniejszosci-na-rynku-pracy [dostęp: 10.02.2019].

Jurgiel-Aleksander A., 2013, Doświadczenie edukacyjne w perspektywie andragogicznej. Studium biograficzno-fenomenograficzne, Gdańsk.

Kto zarobił na Emp@tii? „DGP” bierze pod lupę portal dla bezdomnych, 2014, wiadomosci.dziennik.pl/ wydarzenia/artykuly/454301,kto-zarobil-na-emp-tii-dgp-bierze-pod-lupe-portal-dla-bezdomnych. html [dostęp: 12.11.2015].

Kryńska E., Kwiatkowski E., 2013, Podstawy wiedzy o rynku pracy, Łódź.

Magierek D., 2009, Zmiany polityki społecznej w sferze pracy [w:] R. Gabryszak, D. Magierek (red.), Wprowadzenie do polityki społecznej, Warszawa.

Orczyk J., 2008, Polityka społeczna. Uwarunkowania i cele, wyd. 2, Poznań.

Polak M., 2009, Pojecie, zakres i geneza polityki społecznej [w:] R. Gabryszak, D. Magierek (red.), Wprowadzenie do polityki społecznej, Warszawa.

praca.gov.pl:a, www.praca.gov.pl/eurzad/index.eup\#/rejestracja/ankieta [dostęp: 07.02.2018].

praca.gov.pl:b, www.praca.gov.pl/eurzad/index.eup\#/rejestracja/daneSzczegolowe/umiejetnosci, [dostęp: 07.02.2018]. 
Raport Work Service: Barometr Rynku Pracy X, 2018, https://www.porp.pl/uploads/original/g2/201 8_09/4e037553977229f7ee8f7afcc4b977e5.pdf [dostęp 10.02.2019].

Rutkowski M., 2018, Smartfon jako nieodłączny element studiowania. O poszukiwaniu wiedzy przez studentów w internecie [w:] G. Penkowska (red.), Smartfon - uniwersalne medium poczq̨tku XXI wieku, Gdańsk.

Stańczyk P., 2013, Człowiek, wychowanie i praca w kapitalizmie. W stronę krytycznej pedagogiki pracy, Gdańsk.

Konat G., 2009, Antypolityka społeczno-ekonomiczna, czyli niedobór w gospodarce 2 [w:] P. Szumlewicz, J. Majmurek (red.), Stracone szanse? Bilans transformacji 1989-2009, Warszawa.

szafir.kir.com.pl/eshop-web/items.html [dostęp: 29.06.2018].

Theiss M., Kurowska A., Petelczyc J., Lewenstein B., 2017, Obywatel na zielonej wyspie. Polityka społeczna i obywatelstwo społeczne w Polsce w dobie europejskiego kryzysu ekonomicznego, Warszawa.

Ustawa z dnia 20 kwietnia 2004 r. o promocji zatrudnienia i instytucjach rynku pracy, t.j. Dz. U. z 2018 r., poz. 1265 z późn. zm.

\section{Biogram}

Mateusz Rutkowski - magister pracy socjalnej, student I roku studiów doktoranckich z zakresu Pedagogiki w Instytucie Pedagogiki Wydziału Nauk Społecznych Uniwersytetu Gdańskiego. Badawczo interesuje się zjawiskiem bezrobocia i jego społecznymi implikacjami, pracą socjalną w kontekście zmienności metod wsparcia oraz wykorzystaniem nowych technologii w życiu codziennym. 